\title{
Short Communication: The higher laccase enzyme producer, Cerrena sp. BMd.TA.1, isolated from Gunung Rinjani National Park, West Nusa Tenggara, Indonesia
}

\author{
SARAH ASIH FAULINA ${ }^{1}$, MUHAMAD IRFANI ${ }^{2}$, SYAMSUL FALAH ${ }^{2}$, ASEP HIDAYAT $^{1, \bullet}$, \\ APRI HERI ISWANTO ${ }^{3, \bullet \vee}$ \\ ${ }^{1}$ Laboratory of Forest Microbiology, Forest Research and Development Center, Research, Development and Innovation Agency, Ministry of \\ Environment and Forestry. Jl. Gunung Batu No. 5, Bogor 16610, West Java, Indonesia. Tel.: +62-251-8633234, 7520067; Fax.: +62-251-8638111, \\ •email: ashephidayat12@gmail.com \\ ${ }^{2}$ Departement of Biochemistry, Faculty of Mathematics and Natural Sciences, Institut Pertanian Bogor. Jl. Meranti, Kampus IPB Dramaga, Bogor 16680, \\ West Java, Indonesia \\ ${ }^{3}$ Department of Forest Product, Faculty of Forestry, Universitas Sumatera Utara. Jl. Tri Dharma Ujung No. 1, Kampus USU, Medan 20155, North \\ Sumatra, Indonesia. Tel.: +62-61-8220605, ^email: apri@usu.com
}

Manuscript received: 7 July 2020. Revision accepted: 28 July 2020.

\begin{abstract}
Faulina SA, Irfani M, Falah S, Hidayat A, Iswanto AH. 2020. Short Communication: The higher laccase enzyme producer, Cerrena sp. BMd. TA.1, isolated from Gunung Rinjani National Park, West Nusa Tenggara, Indonesia. Biodiversitas 21: $3837-3842$. Lies in the Wallace line, Gunung Rinjani National Park (GRNP) offers unique biodiversity, fungi included. Fungal enzymes have been unceasingly searched and studied for various applications, particularly for biodegradation. Fungal laccase enzyme showed prospective environmental-friendly approach in treating industrial effluent, remazol brilliant blue R (RBBR) which is used as a synthetic dye. This study aimed to explore the laccase-producing fungi from the GNRP, as well as investigate their ability in decolorizing RBBR. The study discovered that the most prospective fungi isolate, molecularly identified as Cerrena sp. BMd.TA.1, produced a high level of laccase (> $2300 \mathrm{U} \mathrm{mL}^{-1}$ ) and manganese peroxidase (MnP, $\left.300 \mathrm{U} \mathrm{mL}^{-1}\right)$. In the application of this isolate, the laccase showed as predominant enzyme in RBBR decolorization process and the RBBR could be decolorized more than $80 \%$ at $24 \mathrm{~h}$ reaction. It suggested that Cerrena sp BMd.TA.1 isolate is highly potential as laccase enzyme producer and may be considered for further investigations in its applications for biodegradation, especially of dyes effluent.
\end{abstract}

Keywords: Biodegradation, dye effluent, enzymatic reaction, white-rot fungi

Abbreviations: GNRP: Gunung Rinjani National Park, RBBR: remazol brilliant blue R, WRF: white-rot fungi, MnP: manganese peroxidase, DMP: 2,6-dimethoxyphenol

\section{INTRODUCTION}

Indonesia is one of the 17 global megadiverse countries with two of the world's 25 biodiversity hotspots, and the highest number of protected areas in the term of biodiversity conservation (von Rintelen et al. 2017). As protected areas, national parks serve as field laboratories for biodiversity studies. One of Indonesian national parks is Gunung Rinjani National Park (GRNP), which composted of the tropical rain forests located in West Nusa Tenggara, Indonesia. This area consists of various ecosystem types, ranging from sub-montana to montana forest and savanna (Sadikin et al. 2017). The various ecosystem types resulted in unique biodiversities that have been studied from basic to applied biotechnology (von Rintelen et al. 2017). Darajati et al. (2016) reported that the great potential value of microbial diversity was still underexplored.

One of biotechnology use of microbes, particularly the white rot fungi (WRF), is their ligninolytic enzymes. These enzymes play significant role in mineralizing polycyclic aromatic, polychlorinated, petroleum hydrocarbon, phenolic, and dyestuffs, as well as degrading whole biomass (lignin, cellulose, and hemicellulose) naturally (Wulandari et al. 2014; Suharyanto et al. 2012; Yanto et al. 2017; Rodríguez-Couto 2017). Other applications in biotechnology are for food, biosensor, biopulping, biobleaching, and biofuel (Septiningrum and Pramuaji 2017; Järvinen et al. 2012; Rodríguez-Couto 2017). Among ligninolytic enzymes, laccase and manganese peroxidase $(\mathrm{MnP})$ are widely used in biotechnological application (Falade et al. 2017).

Exploring the substrate-specific laccase and $\mathrm{MnP}$ production is very important for industrial application in order to obtain high yield and economic values (Desai and Nityanand 2010). In this study, selection of the prospective WRF isolated from GNRP was screened for their laccase and $\mathrm{MnP}$ production, as well as its capability to decolorize remazol brilliant blue $\mathrm{R}$ (RBBR) in the fungal culture. 


\section{MATERIALS AND METHODS}

\section{Sample collections}

Eighteen fungi isolate used in this study were isolated and purified from fungal bodies found in Gunung Rinjani National Park (GRNP), West Nusa Tenggara, Indonesia at the elevation of 1000-1500 m asl., that were reached from Senaru Post Main gates (Figure 1.). Trametes hirsuta D7 was isolated previously and used as control (Yanto et al. 2017). They were grown on potato dextrose agar (PDA), maintained periodically and kept at Indonesian Tropical Forest-Culture Collection (INTROF-CC); Forest Research and Development Centre; Research, Development, and Innovation Agency; Ministry of Environmental and Forestry.

\section{Chemicals}

All chemicals used in this study were purchased from Sigma, USA and Himedia, India. Those were $2,2^{\prime}$-azinobis(3-ethylbenzthiazoline)-6-sulphonate (ABTS), agar, glucose, syringaldazine, 2,6-dimethoxyphenol (DMP), gallic acid (GA), and other chemicals at the highest purity available.

\section{Fungal selection and identification}

Eighteen fungal isolates with addition T. hirsuta D7 isolate as the positive control, were initially evaluated for its ability to decolorize $100 \mathrm{mg} \mathrm{L}^{-1}$ of RBBR in PDA media containing glucose $\left(20 \mathrm{~g} \mathrm{~L}^{-1}\right)$, potato $\left(200 \mathrm{~g} \mathrm{~L}^{-1}\right)$, and agar $\left(15 \mathrm{~g} \mathrm{~L}^{-1}\right)$. The most active isolates in comparison to positive control were chosen and screened based on ligninolytic enzyme production by three qualitative methods (Lonergan et al. 1993; Hidayat and Tachibana 2013). PDA was used as the fungal culture medium, with addition of dimethoxyphenol (DMP), gallic acid, or syringaldazine. The cultures were incubated at $25{ }^{\circ} \mathrm{C}$ for 7 $\mathrm{d}$ in the first selection, and 4-6 $\mathrm{d}$ in the second selection. The $\mathrm{MnP}$ and laccase enzyme productions were quantified in the last screening. The fungal isolates with color appearance and mycelium growth ratio more than $100 \%$ were chosen and cultured into $20 \mathrm{~mL}$ of potato dextrose broth (PDB) in $100 \mathrm{~mL}$ Erlenmeyer flasks. After incubation for $7 \mathrm{~d}$ at $30^{\circ} \mathrm{C}$, the liquid culture from each sample was subjected for enzymatic assay.

Molecular approach was employed for fungal identification. DNA was obtained from mycelia cultured in PDB for $7 \mathrm{~d}$ and extracted using DNA Wizard Kit (Promega, USA) according to the method described by manufacturer. The internal transcribed spacer ITS region (Jellison and Jasalavich 2000) of ribosomal RNA genes was amplified by polymerase chain reaction (PCR) using ITS1 and ITS4 (White et al. 1990). DNA extracts were amplified with Go Taq ${ }^{\circledR}$ Green Master Mix (Promega, USA) according to the manufacturer's instructions. The purified PCR products were Sanger sequenced using the same PCR primers (First Base Sequencing Service, Singapore). Sequences were aligned and compared by BLAST searches in the National Center for Biotechnology Information (NCBI) GenBank database (http://www.ncbi.nlm.nih.gov/). The phylogenic tree was constructed with maximum likelihood method using MEGA 7 software.

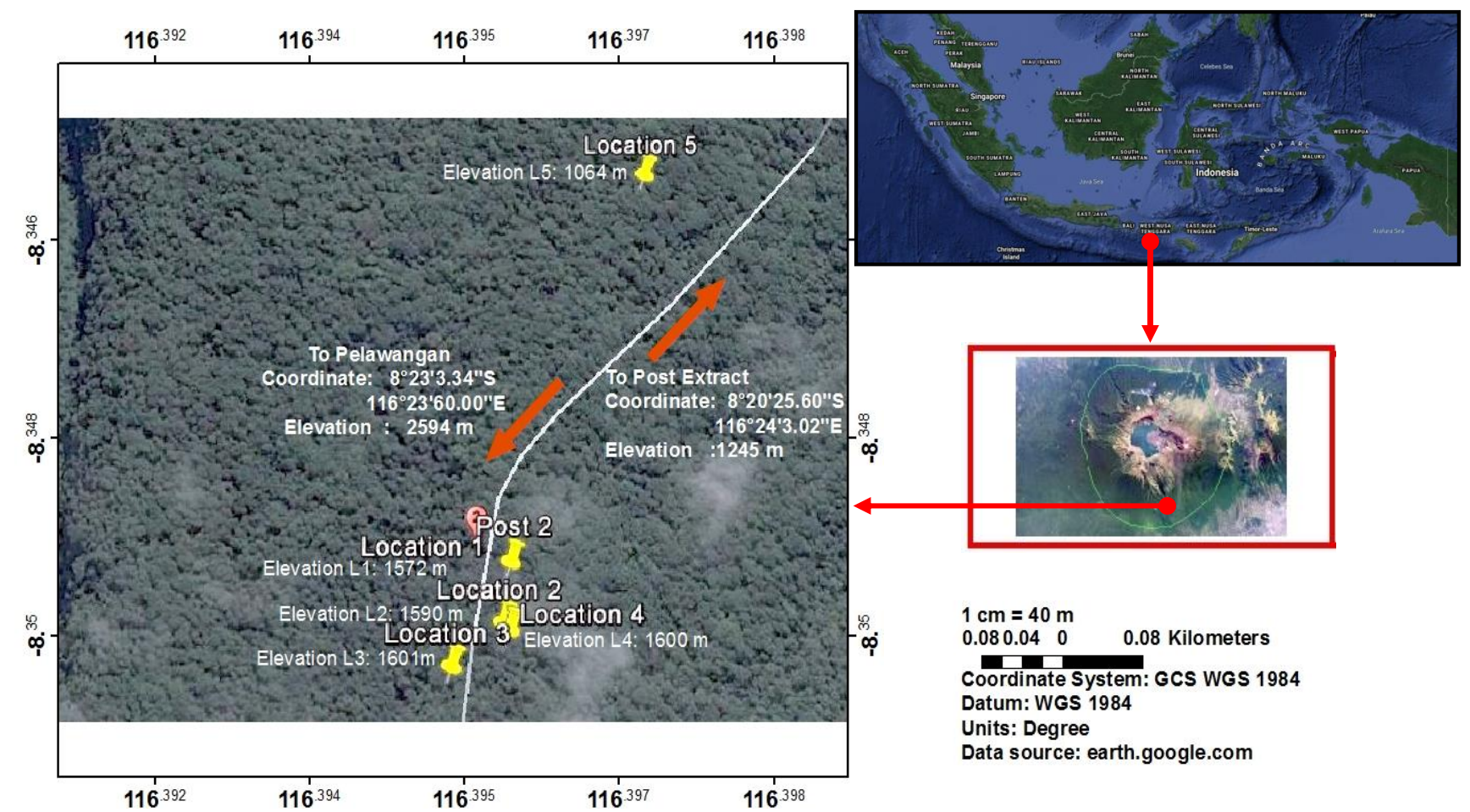

Figure 1. Map of sampling location in Gunung Rinjani National Park, West Nusa Tenggara, Indonesia 
RBBR decolorization by Cerrena sp. BMD. TA. 1

The decolorization of RBBR was evaluated using PDB as culture medium. The amount of RBBR in the culture was $100 \mathrm{mg} / \mathrm{L}$. Dyes were added after 2, 4, and $6 \mathrm{~d}$ of Cerrena sp. BMD. TA. 1 cultivation. After dye was added, the mix was incubated for additional $24 \mathrm{~h}$ before measurement. Five milliliters of culture mix was sampled and centrifuged at $8,000 \mathrm{~g}$. The decrease in supernatants absorbance at the absorbance maximum $(\lambda \max ) 595 \mathrm{~nm}$ was measured using a UV-visible spectrophotometer and monitored. The decolorization was calculated by following formulation:

$$
\% \text { Decolorization }=[1-(\mathrm{C} / \mathrm{C} 0)] \times 100 \%
$$

Where, $\mathrm{C}$ and $\mathrm{C} 0$ refer to initial and final absorbance at $595 \mathrm{~nm}$, respectively. $\mathrm{C}$ and $\mathrm{C} 0$ refer to absorbance dye before and after decolorization at each sampling time. Control was prepared with fungi culture without dye.

\section{Enzymes assays}

The enzymatic activities were quantified directly after decolorization analysis (as mention in section above). Activities of $\mathrm{MnP}$ and laccase were determined by measuring the increase of optical density at $30^{\circ} \mathrm{C}$. MnP activity was assayed using $50 \mathrm{mM}$ malonate buffer and dimethoxyphenol in $20 \mathrm{mM}$ of manganese sulfate $\left(\mathrm{MnSO}_{4}\right)$ at $470 \mathrm{~nm}$ (Wariishi et al. 1992). Laccase activity was assayed by measuring the increase in absorbance at $525 \mathrm{~nm}$ using syringaldazine as a substrate in sodium acetate buffer (Leonowicz and Grzywnowics 1981). Activities were expressed as international units per liter of enzyme, where one unit of activity is defined as the amount of enzyme required to convert $1 \mu \mathrm{mol}$ of substrate in $1 \mathrm{~min}$.

\section{Data analysis}

All results were presented as the mean \pm the standard deviation and calculated by using Microsoft Excel program.

\section{RESULTS AND DISCUSSION}

\section{Selection and identification of fungi}

Total of 18 fungal strains isolated form GNRP were capable to grow and decolorize (disappearance of blue color) RBBR added to agar medium. The RBBR is a dye substrate that is commonly used as an indicator of ligninolytic enzyme activity, providing an easy method for selecting fungi that produce these enzymes (Lonergan et al. 1993; Sumandono et al. 2014). Previously reported $T$. hirsuta D7 produced lignolytic enzyme system and decolorized RBBR (Yanto et al. 2017), hence was used as a positive control in this study. Compared to T. hirsuta D7, the 18 fungal strains showed various decolorization capacities. Four fungal isolates (RJ005, TB.KC.2, KR.M.1, and BMd.TA.1) showed the most extensive RBBR decolorization zone (Figure 2).

Semi-qualitative and quantitative assays were performed on biochemical characteristics. The semiqualitative assay was done with specific substrates; DMP, gallic acid, or syringaldazine, added to agar culture. The fungal isolates have shown different ability that was assessed by the ratio of color appearance and mycelium growth (less or more than $100 \%$, Figure 3). Three isolates have been confirmed producing the high enzymatic activities for both laccase and MnP activity, compared to control isolate Figure 4, which were then subjected for subsequent quantitative assay using UV-Vis spectrophotometer. The result showed that strain BMd.TA.1 produced the highest level of both laccase and MnP activity (Figure 4). Consequently, strain BMd. TA. 1 was selected for further analysis. ITS region of isolate BMd.TA.1 genome was successfully amplified. Sequence of 615 base-pair long was aligned with NCBI database using BLASTn. The fungal isolate BMd.TA.1 showed high similarity (100\% identity) with Cerrena sp. HYB07 partial sequence of small-subunit rRNA with accession number KX599411 (Figure 5).

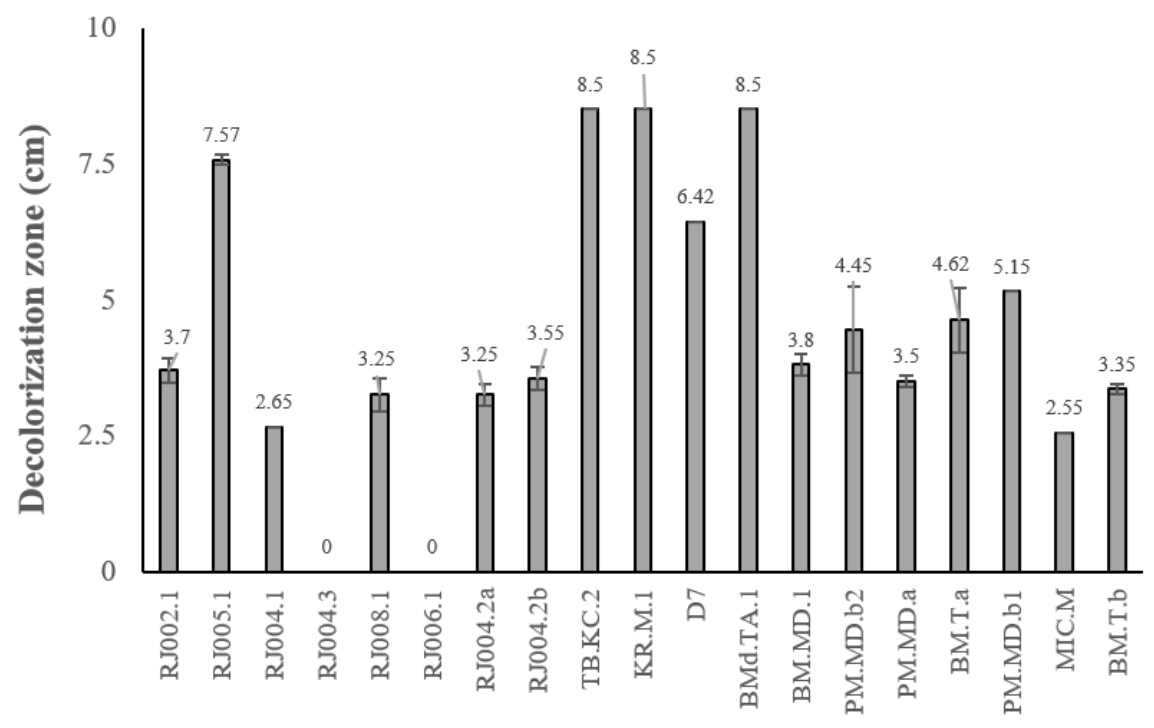

Figure 2. Decolorization of RBBR by 18 pure fungi and 1 fungal (D7) as the control on agar medium observed at $7 \mathrm{~d}$ 


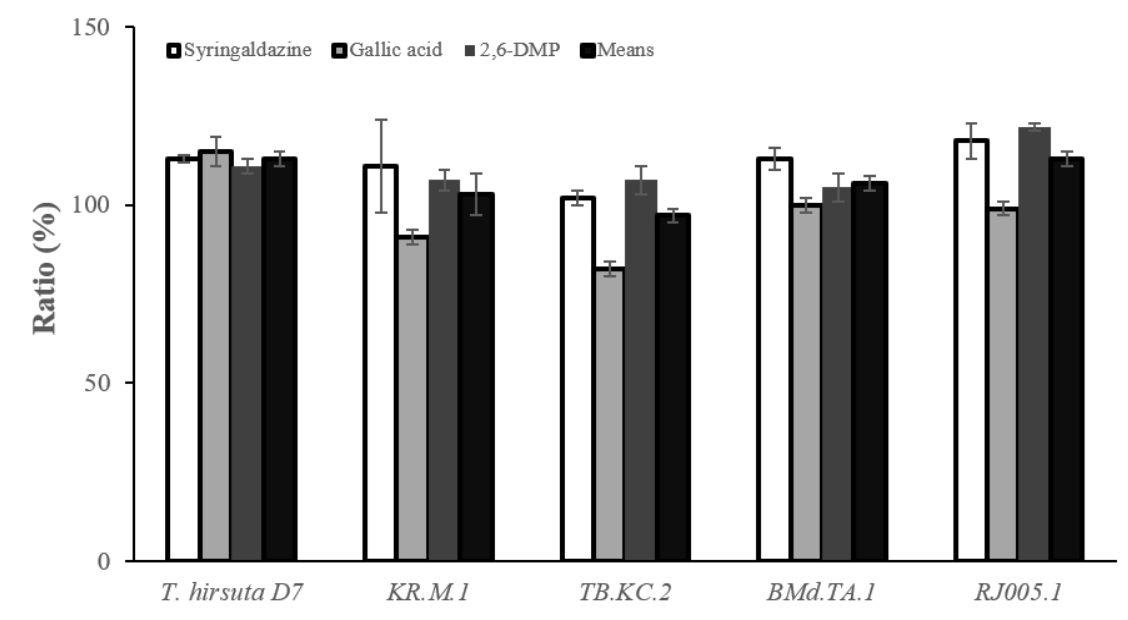

Figure 3. The effects of various substrated on ratio of decolorization and fungal growth. Mean of ratio is the average of quantitative value of all substrates. Syringaldazine, Gallic acid, 2,6-DMP were measured at $6 \mathrm{~d}, 4 \mathrm{~d}$, and $5 \mathrm{~d}$, respectively

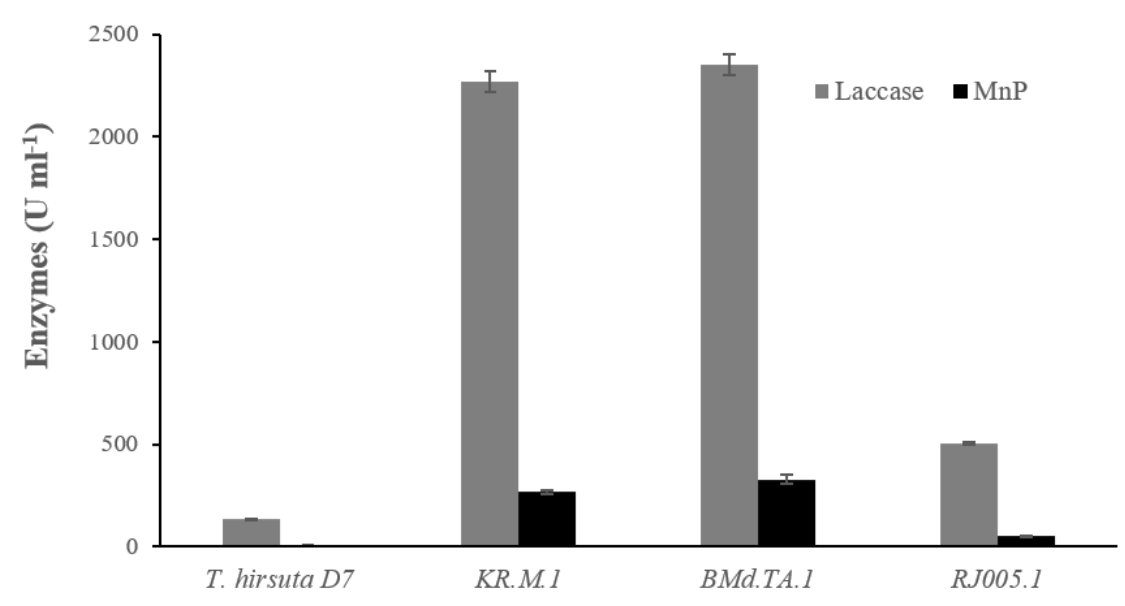

Figure 4. Laccase and MnP activity at liquid culture after $7 \mathrm{~d}$

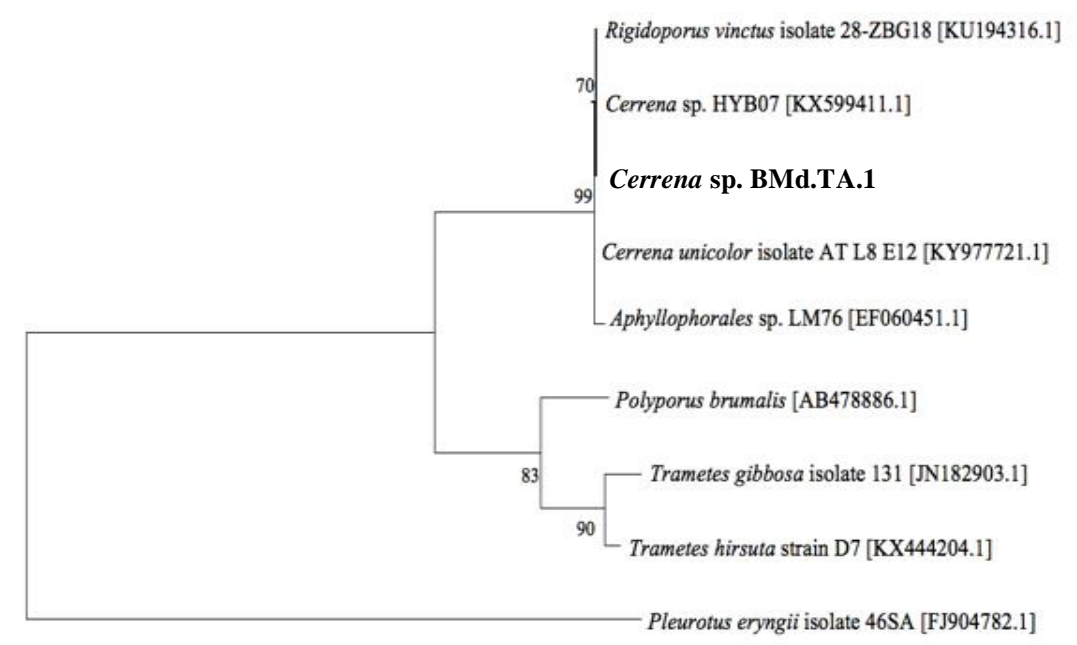

0.10

Figure 5. Phylogenetic relationship of Cerrena sp. BMd.TA.1 and related species sequences. The numbers in parentheses are NCBI accession number 


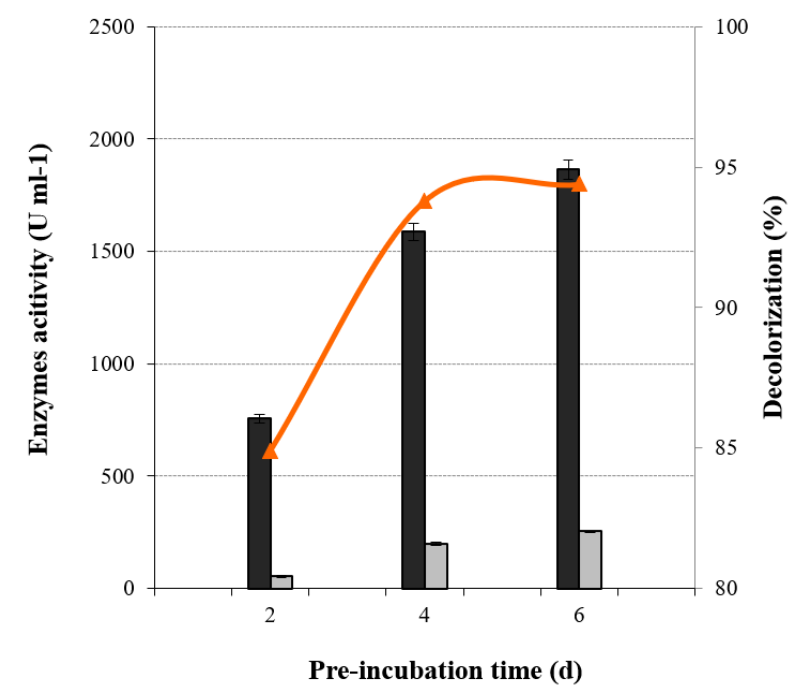

Figure 6. Effect of pre-incubation time on RBBR decolorization $(\boldsymbol{\Lambda})$, and Laccase (black bars) and $\mathrm{MnP}$ (grey bars) enzyme activity during the decolorization process by Cerrena sp. BMd.TA 1 in liquid culture

\section{Decolorization of RBBR by fungal culture BMd.TA.1}

The capability of Cerrena sp. BMd.TA.1 in decolorizing RBBR was also investigated. The dye solution was added at 2-d intervals pre-incubation and analyzed 24 $\mathrm{h}$ after added to test total dye absorbance. Cerrena sp. BMd.TA.1 was able to decolorize RBBR more than $80 \%$ after $24 \mathrm{~h}$ (Figure 6). When pre-incubation of fungal Cerrena sp. BMd.TA.1 was extended (to 4 and 6 d), the decolorization increased about $10 \%$ than shorter preincubation $(2 \mathrm{~d})$.

\section{Discussion}

BMd.TA.1 was identified Cerrena sp. Generally, morphology of genus Cerrena is characterized through dimitic or trimitic hypal system, nonamyloid, hyaline basidiospore, and white rot habitat (Lee and Lim 2010). Cerrena and Trametes were closely related, but the bipolar mating type and clarified generative hyphae of Cerrena could be distinguished as a separate genus (Ryvarden 1984). In previous studies, Cerrena sp. was reported to produce laccase enzyme with activity up to $400 \mathrm{U} \mathrm{mL}^{-1}$ (Sonulashvili et al. 2015; Kachlishvili et al. 2014; Yang et al. 2014; Hidayat and Tachibana 2013). In this study showed that BMd.TA.1 isolate produced the highest laccase enzyme ( $2300 \mathrm{U} \mathrm{mL}^{-1}$, Figure 4), even when it was cultivated in liquid culture without the addition of enzyme co-factors and inducers. Moreover, this isolate also had highest $\mathrm{MnP}$ enzyme activity among isolates tested in this study.

Cerrena sp. BMd.TA.1 was able to decolorize RBBR in liquid culture in this study. The decolorization was increased with the addition of pre-incubation time. Previous result showed that RBBR dye was decolorized by laccase from Cerrena unicolor, Cerrena sp. HYBO7 and fungal culture
Cerrena sp. F0607 (Moilanen et al. 2010; Hidayat and Tachibana 2013; Yang et al. 2014). Other studies described that the decolorization of dyes using living fungal should consider bisorption mechanism, which was about 5-50\% of total color removal (Mou et al. 1991; Hadibarata et al. 2012a). In our studies, it showed that the isolate could decolorize dyes but it was not significantly tough enough as dye removal, because the color of mycelium of fungal clearly the same as those of the control. Furthermore, RBBR decolorization is used to estimate and select the ligninolytic enzyme activities. Two ligninolitic enzymes were detected during RBBR decolorization by Cerrena sp. BMd.TA.1, those are laccase and MnP. The highest enzyme activity was monitored from laccase and showed in increasing activity when incubation length was extended (Figure 6). These results revealed that the laccase has an important role in breaking down and decolorizing RBBR

Decolorization rate was obtained as result of the decreased visible absorbance, changing the blue color to colorless. Decolorization also indicated that the chromophoric group was broken down into several RBBR metabolite products (Hadibarata et al. 2012b). More details, laccase was able to oxidize RBBR to intermediate product, sodium 1-amino-9,10-dioxo-9,10-dihy-droanthracene-2sulfonate $(\mathrm{m} / \mathrm{z}=341,-\mathrm{H})$ and sodium 2-((3-aminophenyl) sulfonyl)ethyl sulfate $(\mathrm{m} / \mathrm{z}=303,-\mathrm{H})$ (Sari et al. 2012; Hadibarata et al. 2012b). Even though, the pathway of RBBR transformation by Cerrena sp. BMd.TA.1 was not investigated in this study, the decolorization was done truly by this fungus (Figure 6). Decolorization of RBBR is a simple indication through enzymatic reaction and could be used as an approach to determine the ability of fungi in xenobiotic biodegradation studies (Machado et al. 2005). According to the results in this study, the fungus Cerrena sp BMd.TA.1 isolated from GRNP, Senaru section particularly, promises as an alternative fungal agent for detoxification and decolorization of dyes effluent as well as on the biodegradation application in the broader areas.

\section{ACKNOWLEDGEMENTS}

The authors are grateful to the GRNP, FRDC (Forest Research and Development Center), and INTROF-CC for allowing us to collect some fungal samples, providing all the necessary facilities and fungal strains. We appreciated all researchers and technicians at Forest Microbiology Laboratory of FRDC for supporting and encouraging our laboratory works and manuscript writing. Sarah Asih Faulina, Asep Hidayat, and Syamsul Falah designed the study. Sarah Asih Faulina, Asep Hidayat and Muhamad Irfani performed the experiments. Sarah Asih Faulina and Asep Hidayat analyzed and interpreted data. Sarah Asih Faulina, Asep Hidayat and Apri Heri Iswanto written and edited manuscripts. All authors reviewed and approval of the final manuscript. 


\section{REFERENCES}

Darajati W, Pratiwi S, Herwinda E., Radiansyah AD, Nalang VS, Nooryanto B, Rahajoe JS, Ubaidillah R., Maryanto I, Kurniawan R. Prasetyo TA, Rahim A, Jefferson J, Hakim F. 2016. Indonesia Biodiversity Strategy and Action Plan 2015-2020. Kementerian Perencanaan Pembangunan Nasional/BAPPENAS. Indonesia [Indonesian]

Desai SS, and Nityanand, C. 2011. Microbial laccases and their applications: a review. Asian J Biotechnol 3 (2): 98-124.

Falade AO, Nwodo UU, Iweriebor BC, Green E., Mabinya LV, Okoh AI 2017. Lignin peroxidase functionalities and prospective applications. Microbiol Open 6 (1): e00394.

Hadibarata T, Yusoff ARM, and Kristanti RA. 2012b. Decolorization and metabolism of anthraquinone-type dye by laccase of white-rot fungi Polyporus sp. S133. Water Air Soil Pollut 223(2): 933-941.

Hadibarata T, Yusoff ARM, Aris A, Salmiati, Hidayat T, Kristanti RA 2012a. Decolorization of azo, triphenylmethane, and anthraquinone dyes by laccase of a newly isolated Armillaria sp. F022. Water Air Soil Pollut 223 (3): 1045-1054.

Hidayat A. Tachibana S. 2013. Degradation of 2, 4, 8 trichlorodibenzofuran by a new isolate of Cerrena sp. F0607. Int Biodeterior Biodegrad 77: 51-55.

Järvinen J, Taskila S, Isomäki R, Ojamo H. 2012. Screening of white-ro fungi manganese peroxidases: a comparison between the specific activities of the enzyme from different native producers. AMB Express 2 (1): 62.

Jellison J, Jasalavich C. 2000. A review of selected methods for the detection of degradative fungi. Intl Biodeterior Biodegrad 46 (3): 241 244.

Kachlishvili E, Metreveli E, Elisashvili V. 2014. Modulation of Cerrena unicolor laccase and manganese peroxidase production. SpringerPlus 3 (1): 463.

Lee JS, Lim YW. 2010. Cerrena aurantiopora sp. nov. (Polyporaceae) from eastern Asia. Mycologia 102 (1): 211-216.

Leonowicz A, and Grzywnowicz K. 1981. Quantitative estimation of laccase forms in some white-rot fungi using syringaldazine as a substrate. Enzyme Microbial Technol 3 (1): 55-58.

Lonergan GT, Jones CL, Mainwaring DE. 1993. The effect of temperature and culture medium on the degradative activity of Phanerochaete chrysosporium evaluated using three qualitative screening methods. Int Biodeterior Biodegrad 31 (2): 107-114.

Machado KMG., Matheus, DR, Bononi VLR. 2005. Ligninolytic enzymes production and Remazol Brilliant Blue $\mathrm{R}$ decolorization by tropical Brazilian basidiomycetes fungi. Braz J Microbiol 36 (3): 246-252.

Moilanen U, Osma JF, Winquist E, Leisola M, Couto SR. 2010 Decolorization of simulated textile dye baths by crude laccases from Trametes hirsuta and Cerrena unicolor. Eng Life Sci 10 (3): 242-247.

Mou DG, Lim KK, Shen HP. 1991. Microbial agents for decolorization of dye wastewater. Biotechnol Adv 9 (4): 613-622.
Rodríguez-Couto S. 2017. Industrial and environmental applications of white-rot fungi. Mycosphere 8 (3): 456-466.

Ryvarden L. 1984. Type studies in the Polyporaceae 16. Species described by J.M. Berkeley, either alone or with other mycologists from 1856 to 1886. Mycotaxon 20 (2): 329-363.

Sadikin PV, Arifin HS, Pramudya B, Mulatsih S. 2017. Carrying capacity to preserve biodiversity on ecotourism in Mount Rinjani National Park, Indonesia. Biodiversitas 18 (3): 978-989.

Sari AA, Tachibana S, Muryanto. 2012. Correlation of ligninolytic enzymes from the newly-found species Trametes versicolor U97 with RBBR decolorization and DDT degradation. Water Air Soil Pollut 223 (9): 5781-5792.

Septiningrum K, Pramuaji I. 2017. Aplikasi enzim di industri pulp dan kertas: I. Bidang pulp. J Selulosa 7 (1): 1-16. [Indonesian]

Sonulashvili G, Spinder D, Jimenez-Tobon GA, Jaspers C, Kerns G, Penninckx MJ. 2015. Production of a high level of laccase by submerged fermentation at 120-L scale of Cerrena unicolor C-139 grown on wheat bran. CR Biol 338 (2): 121-125.

Suharyanto, Kresnawaty I, Prakoso HT, Eris DD. 2012. Aktivitas ligninolitik Omphalina sp. hasil isolasi dari TKKS dan aplikasinya untuk dekolorisasi limbah kosmetik. Menara Perkebunan 80 (2): 48 56. [Indonesian]

Sumandono T, Saragih H, Migirin, Watanabe T, and Amirta R. 2014. Decolorization of Remazol Brilliant Blue R by new isolated white-rot fungus collected from tropical rain forest in East Kalimantan and its ligninolytic enzyme activity. Procedia Environ Sci 28: 45-51.

von Rintelen K, Arida E, Häuser C. 2017. A review of biodiversity-related issues and challenges in megadiverse Indonesia and other Southeast Asian countries. Res Ideas Outcomes 3: e20860. DOI: 10.3897/rio.3.e20860

Wariishi H, Valli K, Gold MH. 1992. Manganese (II) oxidation by manganese peroxidase from the basidiomycete Phanerochaete chrysosporium. J Biol Chem 267 (33): 23688-23695.

White TJ, Bruns T, Lee S, Taylor J. 1990. Amplification and direct sequencing of fungal ribosomal RNA genes for phylogenetics. PCR Protoc 18:315-322.

Wulandari FY, Ratnaningtyas NI, Dewi RS. 2014. Dekolorisasi limbah batik menggunakan limbah medium tanam Pleurotus ostreatus pada waktu inkubasi yang berbeda. Scripta Biologica 1 (1): 71-75. [Indonesian]

Yang J, Lin Q, Ng T B, Ye X, Lin, J. 2014. Purification and characterization of a novel laccase from Cerrena sp. HYB07 with dye decolorizing ability. PLoS ONE 9 (10): e110834. DOI: 10.1371/journal.pone.0110834.

Yanto DHY, Hidayat A, Tachibana S. 2017. Periodical biostimulation with nutrient addition and bioaugmentation using mixed fungal cultures to maintain enzymatic oxidation during extended bioremediation of oily soil microcosms. Int Biodeterior Biodegrad 116: $112-123$ 